\title{
Refinement of Peach Cover Spray Programs for Management of Brown Rot at Harvest
}

\author{
Norman Lalancette, ${ }^{\dagger}$ Lorna L. Blaus, and Peninah Engel \\ Rutgers University, Department of Plant Biology, Rutgers Agricultural Research and Extension Center, Bridgeton, \\ NJ 08302-5919
}

\begin{abstract}
Peach cover spray applications of the protectant fungicide captan were previously shown to significantly reduce brown rot caused by Monilinia fructicola during the preharvest fruit ripening periods in the 2012 through 2015 growing seasons. The protectants sulfur, ziram, and thiram failed to yield this benefit. Percentage disease control with captan ranged from 50 to $69 \%$. Results of a bioassay indicated that the mechanism for this control was the creation of an effective, persistent fungicide residue on the fruit surface. Given these findings, the current 2017 to 2018 study was initiated to further refine the cover spray program. Cover spray applications of captan were made at lower rates and fewer timings with the goal of minimizing fungicide usage while maintaining control. High concentrations of the protectants sulfur and ziram were also examined in cover spray programs to determine whether greater concentrations could improve control. Results of the captan treatments from both years showed that the concentration could be reduced $17 \%$, from 3.36 to $2.80 \mathrm{~kg} / \mathrm{ha}$ active ingredient, without a significant increase in rot at harvest. Disease control at this medium rate was $69 \%$ in 2017 and $51 \%$ in 2018 . The late season timing treatment, which consisted of the final two cover sprays at fifth and sixth cover, significantly reduced brown rot at harvest and provided control equivalent to the full cover spray program consisting of seven applications. Thus, a buildup of residue from many cover sprays is not needed to achieve control. As hypothesized, the midseason treatments, which consisted

remained on fruit for adequate control. However, the early season treatment, which consisted of sprays at shuck split, first cover, and second cover, provided $40 \%$ control, even though the bioassay showed that an effective residue was not present during the preharvest period. Brown rot management for this treatment was probably caused by inhibition of quiescent or latent infections on young green fruit. If confirmed, this novel finding indicates that high levels of latent infections are possible in eastern U.S. peach growing regions. Finally, higher rates of sulfur and ziram cover sprays were still ineffective for providing brown rot control at harvest. Comparison of half maximal effective concentration values calculated from the dose-response models confirmed that the sulfur and ziram intrinsic efficacies were too low for adequate control, even at the highest registered rates. These findings demonstrated that late season captan cover sprays can contribute significantly to control of brown rot at harvest, thereby augmenting the efficacy of preharvest fungicide programs. The year-to-year consistency of control should also be improved because heavy rainfall during the preharvest period did not reduce control by the captan residue. Furthermore, any reduction of the $M$. fructicola population by the captan cover sprays should reduce selection pressure against the site-specific fungicides commonly used during the preharvest period. The development of resistance to captan, a multisite protectant fungicide, is not likely, so this resistance management strategy should be sustainable.
\end{abstract} of two sprays at third and fourth cover, did not provide control of brown rot at harvest. The bioassay confirmed that insufficient residue
Keywords: chemical disease management, fruit, fungi, tree fruits
In commercial peach (Prunus persica L. Batch) orchards located in the eastern United States, disease management with fungicides can be divided into four periods of control. During the dormant period, one fungicide application typically is made in late fall or late winter, before bud swell, for management of leaf curl caused by Taphrina deformans (Berk.) Tulasne (Jones and Sutton 1996). Fungicide applications during the spring bloom and the preharvest fruit ripening periods are made primarily for management of brown rot blossom blight and fruit rot, respectively, caused by Monilinia fructicola (G. Winter) Honey (Anderson 1956; Ogawa et al. 1995). Two or three applications, typically with systemic or site-specific fungicides, are performed during each of these periods (Ward et al. 2017).

The fourth period for peach disease management, typically called the cover spray period, occurs between the bloom and preharvest periods. This period begins at initiation of shuck split, the time when growth of the young fruit causes the surrounding calyx to split, exposing the fruit surface to infection for the first time. Fungicide

${ }^{\dagger}$ Corresponding author: N. Lalancette; lalancette@ njaes.rutgers.edu

Funding: This research was supported in part by the U.S. Department of Agriculture National Institute of Food and Agriculture Hatch Project NJ12162 and by the Pennsylvania Peach and Nectarine Research Program.

The author(s) declare no conflict of interest.

Accepted for publication 18 November 2019.

(C) 2020 The American Phytopathological Society applications during the cover spray period are made during this time for management of summer diseases such as peach scab (Hendrix 1995), rusty spot (Furman et al. 2003), and anthracnose (Bernstein and Miller 1995; Jones and Sutton 1996). Depending on the cultivar's harvest date, two to eight fungicide applications, generally at 10- to 14-day intervals, are performed during the cover spray period (Ward et al. 2017). However, unlike the bloom and preharvest applications, the cover sprays typically are protectant fungicides, most commonly captan or sulfur.

In a 2010 fungicide efficacy field study on peach cultivar Autumnglo, one particular treatment program used captan for the bloom, shuck split, and all eight cover sprays but lacked the final three preharvest applications (N. Lalancette and K. McFarland, unpublished). Regardless of this latter omission, this program reduced brown rot incidence by $60 \%$. This result suggested that fungicide applications during the cover spray period can contribute to control of brown rot at harvest. A subsequent study conducted from 2012 through 2015 confirmed that a captan cover spray program can significantly and consistently control brown rot at harvest; fruit rot control ranged from 50 to $69 \%$ (Lalancette et al. 2017). Other currently registered protectant fungicides, namely sulfur, ziram, and thiram, were applied in similar cover spray programs but did not provide this benefit. Additional experimentation, using a bioassay (Lalancette et al. 2015a), revealed that the mechanism of control was the presence of effective fungicide residue on the fruit surface rather than a reduction of inoculum from blossom blight cankers.

Although commercial peach growers can obtain the additional brown rot control benefit by simply using captan cover spray programs at the tested rate (Lalancette et al. 2017), further refinement 
of the approach would allow more efficient implementation. Thus, the first objective of the current study was to determine whether the same level of control can be achieved with lower rates of captan. The captan application rate in all previous studies was $3.36 \mathrm{~kg} / \mathrm{ha}$ of active ingredient, which was midpoint of the registered rate range of 2.24 to $4.48 \mathrm{~kg} / \mathrm{ha}$. A second objective was to determine whether only some of the cover spray application timings are needed for control. Because the bioassay indicated that fungicide residual activity on fruit is the control mechanism, perhaps only the final one or two cover sprays are necessary. In this case, we would hypothesize that only the late season cover sprays contribute to brown rot control, whereas early and midseason cover applications do not.

A third objective of this study was to reexamine the efficacy of sulfur and ziram cover spray programs, but at much higher application rates. In the previous study, sulfur and ziram were evaluated at low and midrange application rates, respectively (Lalancette et al. 2017). In the case of sulfur, this rate was considered adequate for management of scab. However, higher rates of less effective materials can sometimes improve control, and current registrations for these materials allow this augmentation. Also, the dose-response curves for these materials should be derived to compare their intrinsic efficacy to that of captan. Finally, in addition to contributing to brown rot management, these refined programs should be examined for management of scab because this disease is the primary target of the cover spray applications. Initial results of this study have been previously reported (Lalancette and Blaus 2018).

\section{Materials and Methods}

Orchard site. The experiment was conducted during the 2017 and 2018 growing seasons at the Rutgers Agricultural Research and Extension Center, Bridgeton, New Jersey. The experimental orchard consisted of 8-year-old Bounty and GaLa peach (Prunus persica) trees grafted on Baily peach rootstock planted at $7.6 \mathrm{~m}$ tree $\times$ $7.6 \mathrm{~m}$ row spacing. Trees of each cultivar alternated within the rows, and adjacent rows were offset so that each cultivar tree was surrounded by trees of the other cultivar on all four sides. Standard practices for tree management, insect control, and weed control were followed throughout the study (Ward et al. 2017).

Experimental design. In each year of the study, fungicide treatments were arranged in a randomized complete block design with four blocks. Treatment plots consisted of single Bounty trees replicated once in each of the four blocks. Treatments were randomly assigned to the Bounty trees at the beginning of each growing season. The GaLa trees were not used in the study and remained unsprayed. Diseased fruit on these trees, which ripen 1 to 2 weeks before Bounty fruit, provided additional inoculum for infection of Bounty fruit.

Treatments. A total of nine fungicide treatments were applied during the cover spray period in each year of the study. The first three "rate" treatments (low, medium, and high) consisted of the fungicide captan applied at 2.24, 2.80, and $3.36 \mathrm{~kg} / \mathrm{ha}$ of active ingredient. The next three "timing" treatments consisted of captan (same formulation) applied at $3.36 \mathrm{~kg} / \mathrm{ha}$ of active ingredient at early, mid, and late season cover spray timings. Two high-rate protectant fungicide treatments consisted of sulfur at $16.14 \mathrm{~kg} / \mathrm{ha}$ of active ingredient and ziram at $6.81 \mathrm{~kg} / \mathrm{ha}$ of active ingredient. Finally, a standard treatment, included for comparison of brown rot at harvest, consisted of captan at $3.36 \mathrm{~kg} / \mathrm{ha}$ of active ingredient during the cover spray period plus two applications of fenbuconazole at $157.6 \mathrm{~g} / \mathrm{ha}$ during the preharvest period.

Each of the three captan rate treatments, the sulfur high-rate treatment, the ziram high-rate treatment, and the standard were first applied at 5\% shuck split (SS) and then at first through sixth covers (1C through 6C). The two preharvest fenbuconazole sprays for the standard were applied at 15 and 6 to 8 days before harvest. Trees assigned to the early, mid, and late timing treatments received sprays only at SS, $1 \mathrm{C}$, and $2 \mathrm{C} ; 3 \mathrm{C}$ and $4 \mathrm{C}$; and $5 \mathrm{C}$ and $6 \mathrm{C}$, respectively. The initial three sprays were applied at 10- to 12-day intervals, with the remaining cover sprays at approximately 14-day intervals. Application dates were 24 April; 4, 16, and 27 May; 12 and 26 June; and 10 July in 2017 and 4, 14, and 25 May; 6 and 20 June; and 4 and
17 July in 2018. No fungicides were applied during the dormant or bloom period or during the preharvest fruit ripening period (except for the standard).

All treatments were applied to each plot by an airblast sprayer at $935 \mathrm{Liter} / \mathrm{ha}$ volume, $3.4 \mathrm{~km} / \mathrm{h}$ tractor speed, and $690 \mathrm{kPa}$ pressure. A nontreated control treatment was included to indicate the level of disease pressure. The nontreated GaLa trees acted as buffers to minimize spray drift and interplot interference.

Fruit rot assessment. We evaluated fruit rot caused by $M$. fructicola at harvest by examining all fruit on four or more branches selected around the periphery of each treatment tree. Fruit were considered infected if any size brown rot lesion was visible on the fruit surface. The dates of the assessments, which were conducted during the middle of the 1-week harvest period (Ward et al. 2017), were 1 August 2017 and 10 August 2018. The average number of fruits evaluated per treatment tree in 2017 was 73 , with a range of 30 to 85 fruits. In 2018, an average of 77 fruits per tree were examined, with a range of 64 to 83 fruits.

Fungicide residue assessment. The amount of effective fungicide residue on fruit during the preharvest period was assessed at 7 and 21 days after the final cover spray application in both years of the study. Actual assessment dates were 17 and 31 July in 2017 and 24 July and 7 August in 2018. At each assessment, two fruits were selected from each treatment tree, for a total of eight fruits per treatment. One fruit was selected from each side of the tree adjacent to the tree row middles (driving rows). Fruits were submitted to a bioassay to determine the level of fungicide residue resulting from the previous cover sprays (Lalancette et al. 2015a). Briefly, an incubation well consisting of a short section of plastic tubing was installed on one side of each fruit with vacuum grease. A conidial suspension of a single-spore isolate of M. fructicola (Mf012) was pipetted into each well. The suspension medium consisted of a buffer substrate that provided the optimum $\mathrm{pH}$ and nutrients for spore germination. After incubation for $6 \mathrm{~h}$ at $25^{\circ} \mathrm{C}$, the degree of conidia germination was assessed with a compound microscope at $200 \times$ magnification. The level of spore germination is inversely proportional to the amount of fungicide residue on the fruit surface, which can be determined via a standard curve for the fungicide in question. However, because the pathogen examined in this study was identical to the indicator organism used in the bioassay, namely M. fructicola, the percentage of spore germination was used directly as a measure of the amount of effective fungicide residue present.

Dose-response curves. To further define and compare efficacy of the three protectant fungicides and to confirm field results, in vitro dose-response curves were generated for each fungicide. Inoculum for treatments was obtained from 7-day-old cultures of Mf012 grown on potato dextrose agar. Shaker flasks containing an aqueous medium of $0.025 \mathrm{M}$ potassium phosphate buffer plus $0.1 \%$ sucrose and $0.1 \%$ yeast extract were amended with each fungicide at eight or nine different concentrations in a logarithmic series. Nonamended buffer substrate medium served as a control (NTC). Conidia were added to the flasks at a final concentration of $5 \times 10^{4}$ spores $/ \mathrm{ml}$. Flasks were then placed in the dark with gentle agitation at $25^{\circ} \mathrm{C}$. After $6 \mathrm{~h}$ incubation, the germination process was halted by adding formalin at $0.5 \% \mathrm{vol} / \mathrm{vol}$ (Darby 1960 ).

A total of 200 conidia from each flask were examined for germination. A conidium was considered germinated if its germ tube length was at least half the diameter of the spore. The dependent response variable, relative conidia germination (RG) on a 0 to 1 scale, was calculated as $\mathrm{RG}=\%$ germinated (amended) $/ \%$ germinated NTC, or $\mathrm{G}_{\mathrm{TRT}} / \mathrm{G}_{\mathrm{NTC}}$. Three replicate flasks were evaluated for each concentration of each fungicide and the NTC, resulting in a total of 600 conidia assessed per treatment. The entire experiment was performed twice.

Peach scab assessment. Peach scab, caused by Fusicladium carpophilum, was evaluated at harvest on 1 August 2017 and 10 August 2018. During each assessment, 25 fruits were arbitrarily selected from the canopy of each tree, resulting in 100 fruits per treatment. The total number of infected fruits, number of fruits with 1 to 10 lesions, and number of fruits with $>10$ lesions were recorded. From 
these data, overall fruit disease incidence and percentage of fruit in each disease severity category were calculated.

Weather data. Air temperature and rainfall data were recorded by a portable datalogger and associated sensors located at the research station. This weather station is part of the Mesonet Network operated by the Office of the New Jersey State Climatologist. Observations were taken every 2 min and summarized every hour. Hourly temperature and rainfall data were averaged and summed, respectively, for each day of the growing season. The datalogger was located approximately $200 \mathrm{~m}$ from the Bounty test orchard.

Statistical analyses. To examine the response of each treatment to the varying weather conditions in each growing season, separate statistical analyses were conducted for each year of the study. Interest was in determining consistency of treatment response across the two years rather than overall significance of a treatment main effect. Thus, an analysis of variance was performed on each dependent variable in each year of the study for a standard randomized complete block design. All treatment means in each of these analyses were compared via the Bayesian Waller-Duncan $K$-ratio $t$ test with $K=100$ in SAS version 9.4. In each analysis, graphs of standardized residuals were examined for departures from the analysis of variance assumptions of normality, equal error variance, and independence of error terms. If corrections were necessary, the arcsin square root and logarithmic transformations were used for proportional and count data, respectively.

To quantitatively characterize efficacy of the three fungicides, the logistic decline model:

$$
\mathrm{RG}=\mathrm{a}+\left[\mathrm{b} /\left(1+e^{\mathrm{c}(\mathrm{LCONC}-\mathrm{d})}\right)\right]
$$

was fit to each dose-response curve via the nonlinear regression procedure of SAS version 9.4. The model parameters a, b, c, and d define the minimum, maximum - $\mathrm{a}$, shape, and inflection point on the abscissa, respectively; LCONC $=\log _{10}$ (active ingredient concentration). Substitution of $\mathrm{RG}=0.5$ into each derived model allowed estimation of $\mathrm{EC}_{50}$ values, the effective concentration at $50 \%$ inhibition of germination.

\section{Results}

Fungicide rate effect. Cover spray applications of all three captan rate treatments significantly reduced brown rot at harvest relative to the nontreated control (Table 1). However, as expected, none of these treatments were as effective as the standard. In comparison with the high-rate treatment, the addition of fenbuconazole in the standard increased the level of disease control from 78 to $98 \%$ in 2017 and 55 to $93 \%$ in 2018.

In both years of the study, an indirect rate response was evident between brown rot at harvest and captan concentration in the cover sprays (Table 1). As the rate of captan increased, the level of rot decreased. However, the relationship was not linear, as a greater decrease in rot occurred between the low and medium rates than between the medium and high rates. Typically, such a relationship of diminishing returns would be described by the negative exponential model. Based on the percentage disease control observed in both years, a concentration of $2.80 \mathrm{~kg} / \mathrm{ha}$ of captan, the medium rate, was necessary to obtain a $\geq 50 \%$ level of brown rot control. As would be expected given the mathematical relationship, the high-rate treatment increased the degree of control but not significantly.

Results of the bioassay showed that an effective captan residue was present on fruit during the preharvest period for each of the three rate treatments (Table 2). Conidia germination was significantly lower than the control for 11 of the 12 bioassay assessments conducted across both years of the study. These results support the efficacy levels observed at harvest (Table 1). However, unlike the efficacy results, a rate response was not evident in the bioassay data.

Fungicide timing effect. As hypothesized, the two late season cover sprays, which were applied immediately before the preharvest period, significantly reduced brown rot at harvest (Table 1). Significant reductions in conidia germination were observed in the bioassay results, indicating the presence of an effective residue for this treatment (Table 2). Perhaps most importantly, the two-application late season treatment was as effective at controlling brown rot as the seven-application high-rate treatment (Table 1). The levels of brown rot control for both treatments were not significantly different, and percentage disease controls were similar in both years (Table 1).

As also hypothesized, the midseason cover spray applications did not significantly reduce brown rot at harvest (Table 1). Effective residues were not observed during the preharvest period for three of the four assessments; some residue was present at 7 days in 2018 (Table 2). This lack of control was probably caused by residue wash-off or degradation from environmental factors during the 6week period between the final spray at fourth cover (4C) and harvest.

As with the midseason treatment, the early season program was also not expected to provide control of brown rot at harvest. The final early season application, second cover (2C), occurred 10 weeks before harvest, providing plenty of time for loss of effective residue on fruit. However, in both years of the study, the three early season applications significantly reduced brown rot at harvest, providing approximately $40 \%$ control in both years (Table 1). Percentage conidia germination in the four bioassay assessments was not significantly different from that of the control, indicating that an effective fungicide residue was not present during the preharvest period (Table 2). Thus, brown rot control must have occurred during the period of fungicide application, namely shuck split through second cover.

Table 1. Brown rot fruit rot incidence at harvest for cover spray fungicide treatments applied during the 2017 and 2018 growing seasons

\begin{tabular}{|c|c|c|c|c|c|c|c|}
\hline \multicolumn{4}{|c|}{ Treatment } & \multicolumn{2}{|c|}{2017} & \multicolumn{2}{|c|}{2018} \\
\hline Type & Fungicide & Amount (kg/ha) & Application timing ${ }^{y}$ & $\% \operatorname{Rot}^{\mathrm{z}}$ & $\%$ Control & $\% \operatorname{Rot}^{\mathrm{z}}$ & $\%$ Control \\
\hline Nontreated & - & - & - & $62.9 \mathrm{~b}$ & - & $62.4 \mathrm{a}$ & - \\
\hline \multirow[t]{2}{*}{ Standard } & Captan & 3.36 & SS, $1 \mathrm{C}-6 \mathrm{C}$ & & & & \\
\hline & Fenbuconazole & 0.158 & $15,6-8 \mathrm{dph}$ & $1.3 \mathrm{~g}$ & 97.9 & $4.4 \mathrm{e}$ & 92.9 \\
\hline \multicolumn{8}{|c|}{ Fungicide rate effect } \\
\hline Low rate & Captan & 2.24 & SS, $1 \mathrm{C}-6 \mathrm{C}$ & $31.0 \mathrm{cde}$ & 50.7 & $41.4 \mathrm{bcd}$ & 33.7 \\
\hline Medium rate & Captan & 2.80 & SS, $1 \mathrm{C}-6 \mathrm{C}$ & $19.5 \mathrm{ef}$ & 69.0 & $30.8 \mathrm{~d}$ & 50.6 \\
\hline High rate & Captan & 3.36 & SS, $1 \mathrm{C}-6 \mathrm{C}$ & $13.7 \mathrm{f}$ & 78.2 & $27.9 \mathrm{~d}$ & 55.3 \\
\hline \multicolumn{8}{|c|}{ Fungicide timing effect } \\
\hline Early season & Captan & 3.36 & $\mathrm{SS}, 1 \mathrm{C}, 2 \mathrm{C}$ & $37.8 \mathrm{~cd}$ & 39.9 & $37.7 \mathrm{~cd}$ & 39.6 \\
\hline Midseason & Captan & 3.36 & $3 \mathrm{C}, 4 \mathrm{C}$ & $77.0 \mathrm{a}$ & 0.0 & $55.1 \mathrm{ab}$ & 11.7 \\
\hline Late season & Captan & 3.36 & $5 \mathrm{C}, 6 \mathrm{C}$ & $21.4 \mathrm{def}$ & 66.0 & $29.7 \mathrm{~d}$ & 52.4 \\
\hline \multicolumn{8}{|c|}{ Alternative protectants } \\
\hline High rate & Sulfur & 16.14 & SS, $1 \mathrm{C}-6 \mathrm{C}$ & $68.0 \mathrm{~b}$ & 0.0 & $54.4 \mathrm{ab}$ & 12.8 \\
\hline High rate & Ziram & 6.81 & $\mathrm{SS}, 1 \mathrm{C}-6 \mathrm{C}$ & $41.2 \mathrm{c}$ & 34.5 & $49.2 \mathrm{abc}$ & 21.2 \\
\hline
\end{tabular}


Alternative protectants. Cover sprays of sulfur at a high rate failed to significantly reduce brown rot development in both years of the study (Table 1). Sulfur residues on fruit at 7 days after the final cover spray (6C) were sufficient to significantly lower conidia germination in the bioassay (Table 2). However, by 21 days after the $6 \mathrm{C}$ application, these residues were no longer effective. In comparison, cover sprays of ziram at a high rate resulted in residues that significantly reduced conidia germination throughout the preharvest period in both years (Table 2). However, this treatment significantly reduced brown rot at harvest in only one (2017) of the two years, and the level of control was only $35 \%$ (Table 1). Although more effective than sulfur, the high rate of ziram at best provided control equivalent to that of the low rate of captan.

Environmental conditions. In both years of the study, temperatures were approximately 3 to $5^{\circ} \mathrm{C}$ warmer during the preharvest periods than during the cover spray periods (Table 3 ). However, average temperatures during both of these periods were favorable for spore germination and infection. Rainfall accumulations during both the cover spray period and preharvest period were greater in 2017 than in 2018. Nevertheless, in both years of the study, very high levels of cumulative rainfall occurred during the preharvest periods to challenge the ability of the residues to remain on the fruit. The rainfall accumulations observed during the 23- and 25-day preharvest periods, $19.2 \mathrm{~cm}$ (7.6 in.) and $15.2 \mathrm{~cm}$ (6.0 in.) for 2017 and 2018, respectively, were much greater than the 30-year normal of $10.7 \mathrm{~cm}$ (4.2 in.) for the entire month of August.

Dose-response curves. The logistic decline model provided excellent fits to the dose-response data for each of the fungicides analyzed (Fig. 1). Based on the coefficient of determination, calculated as $1-$ SSE/SST, the models described 97 to $99 \%$ of the variation in the data ( $\mathrm{SSE}=$ error sum of squares; $\mathrm{SST}=$ total sum of squares). Comparison of the effective concentrations at $\mathrm{EC}_{50}$ showed that captan had a much higher intrinsic efficacy than either ziram or sulfur. Based on the $\mathrm{EC}_{50}$ values, captan was four times more effective than ziram and almost 11 times more effective than sulfur.

Comparison of the shapes of the dose-response curves revealed a narrow band of efficacy for captan, an intermediate band for sulfur, and a wide band for ziram (Fig. 1). That is, within the range of activity, a small increase in captan concentration caused a dramatic decrease in spore germination. In contrast, much greater increases in concentration were needed for ziram to achieve the same level of inhibition in spore germination. Graphically, this difference was represented by the steep, intermediate, and shallow slopes of the captan, sulfur, and ziram curves, respectively. Mathematically, the logistic decline model's shape parameter, $c$, was highest for captan (8.5), intermediate for sulfur (2.6), and lowest for ziram (1.3).

Peach scab. Disease pressure from $F$. carpophilum, causal agent of peach scab, was very high in both years (Table 4). The majority of fruits $(\geq 74 \%)$ were infected, and more than half of these infected fruits had $>10$ lesions. The standard treatment provided $97 \%$ control in 2017 and $83 \%$ control in 2018.

All three captan rate treatments significantly reduced both scab incidence and severity ( $>10$ lesion category) relative to the nontreated control (Table 4). Across both years of the study, the low-, medium-, and high-rate treatments provided 63,73 , and $78 \%$ control of scab, respectively. However, few significant differences in disease incidence or severity were observed between the three treatments themselves. Only the low-rate treatment in 2018 was observed to have significantly higher scab levels than the medium- and high-rate treatments. As expected, the high-rate treatment was not significantly different from the standard, because both included captan at the same rate during the critical cover spray period.

In both years of the study, scab disease incidence and severity $(>10$ lesion category) on fruit receiving the early and midseason timings were significantly less than observed on nontreated fruit (Table 4). Furthermore, in most assessments disease levels on fruit receiving

Table 2. Bioassay results for estimating fungicide residue on peach fruit treated with different cover spray fungicides, rates, and timings during the 2017 and 2018 growing seasons

\begin{tabular}{|c|c|c|c|c|c|c|c|}
\hline & & & & \multicolumn{4}{|c|}{$\begin{array}{l}\text { Effective fungicide residue } \\
\text { (\% conidia germination) }{ }^{\mathrm{w}}\end{array}$} \\
\hline \multicolumn{4}{|c|}{ Treatment } & \multicolumn{2}{|c|}{$2017^{x}$} & \multicolumn{2}{|c|}{$2018^{x}$} \\
\hline Type $^{y}$ & Fungicide & Amount (kg/ha) & Application timing ${ }^{\mathrm{z}}$ & $7 \mathrm{~d}$ & $21 \mathrm{~d}$ & $7 \mathrm{~d}$ & $21 \mathrm{~d}$ \\
\hline Nontreated & - & - & - & $49.3 \mathrm{ab}$ & $72.8 \mathrm{bc}$ & $58.5 \mathrm{a}$ & $73.9 \mathrm{a}$ \\
\hline \multicolumn{8}{|c|}{ Fungicide rate effect } \\
\hline Low rate & Captan & 2.24 & $\mathrm{SS}, 1 \mathrm{C}-6 \mathrm{C}$ & $9.9 \mathrm{e}$ & $46.7 \mathrm{f}$ & $9.5 \mathrm{de}$ & $40.6 \mathrm{~b}$ \\
\hline Medium rate & Captan & 2.80 & $\mathrm{SS}, 1 \mathrm{C}-6 \mathrm{C}$ & 9.5 ef & $57.8 \mathrm{de}$ & $13.8 \mathrm{~d}$ & $64.0 \mathrm{a}$ \\
\hline High rate & Captan & 3.36 & $\mathrm{SS}, 1 \mathrm{C}-6 \mathrm{C}$ & $6.3 \mathrm{f}$ & $48.9 \mathrm{ef}$ & $4.9 \mathrm{e}$ & $30.6 \mathrm{~b}$ \\
\hline \multicolumn{8}{|c|}{ Fungicide timing effect } \\
\hline Early season & Captan & 3.36 & $\mathrm{SS}, 1 \mathrm{C}, 2 \mathrm{C}$ & $54.5 \mathrm{a}$ & $79.4 \mathrm{ab}$ & $53.7 \mathrm{ab}$ & $73.1 \mathrm{a}$ \\
\hline Midseason & Captan & 3.36 & $3 \mathrm{C}, 4 \mathrm{C}$ & $45.2 \mathrm{~b}$ & $82.4 \mathrm{a}$ & $49.6 \mathrm{~b}$ & $71.0 \mathrm{a}$ \\
\hline Late season & Captan & 3.36 & $5 \mathrm{C}, 6 \mathrm{C}$ & 8.6 ef & $12.2 \mathrm{~g}$ & $8.7 \mathrm{de}$ & $32.4 \mathrm{~b}$ \\
\hline \multicolumn{8}{|c|}{ Alternative protectants } \\
\hline High rate & Sulfur & 16.14 & $\mathrm{SS}, 1 \mathrm{C}-6 \mathrm{C}$ & $32.0 \mathrm{c}$ & $63.8 \mathrm{~cd}$ & $25.0 \mathrm{c}$ & $61.6 \mathrm{a}$ \\
\hline High rate & Ziram & 6.81 & $\mathrm{SS}, 1 \mathrm{C}-6 \mathrm{C}$ & $21.4 \mathrm{~d}$ & $49.1 \mathrm{ef}$ & $20.3 \mathrm{c}$ & $34.6 \mathrm{~b}$ \\
\hline
\end{tabular}

${ }^{w}$ The level of conidia germination is inversely proportional to the amount of fungicide residue present. Means in the same column followed by the same letter are not significantly different according to the Waller-Duncan $K$-ratio $t$ test $(K$-ratio $=100 ; P \leq 0.05)$.

x Assessment times are number of days after application of the final cover spray (6C) on 10 July 2017 and 17 July 2018.

y The standard treatment was not included in the assessment.

z 1C-6C, first through sixth covers; SS, shuck split.

Table 3. Cumulative rainfall and mean temperatures during the cover spray and preharvest periods in each year of the study

\begin{tabular}{|c|c|c|c|c|c|c|c|c|}
\hline \multirow[b]{3}{*}{ Study year } & \multicolumn{4}{|c|}{ Shuck split through final cover } & \multicolumn{4}{|c|}{ Final cover through harvest ${ }^{\mathrm{z}}$} \\
\hline & \multicolumn{2}{|c|}{ Period and duration } & \multirow{2}{*}{$\begin{array}{l}\text { Total rain } \\
(\mathrm{cm})\end{array}$} & \multirow{2}{*}{$\begin{array}{c}\text { Average } \\
\text { temperature }\left({ }^{\circ} \mathbf{C}\right)\end{array}$} & \multicolumn{2}{|c|}{ Period and duration } & \multirow{2}{*}{$\begin{array}{l}\text { Total rain } \\
(\mathrm{cm})\end{array}$} & \multirow{2}{*}{$\begin{array}{c}\text { Average } \\
\text { temperature }\left({ }^{\circ} \mathrm{C}\right)\end{array}$} \\
\hline & Dates & Days & & & Dates & Days & & \\
\hline 2017 & 24 April-10 July & 78 & 32.2 & 20.0 & 10 July-1 August & 23 & 19.2 & 24.7 \\
\hline 2018 & 4 May-17 July & 75 & 23.1 & 21.9 & 17 July-10 August & 25 & 15.2 & 25.0 \\
\hline
\end{tabular}

${ }^{\mathrm{y}}$ A total of seven sprays were applied during the cover spray period in each year.

${ }^{\mathrm{z}}$ Except for the standard treatment, no fungicides were applied during the preharvest period. 
the early season treatment were significantly lower than observed on fruit receiving the midseason sprays. Thus, the early season timing is more critical for scab control than the midseason timing, although both contributed significantly to disease reduction. In contrast, no scab control was evident for the late season application timing.

Sulfur applied at a high rate significantly lowered scab incidence and severity, yielding 93\% control in 2017 and $79 \%$ control in 2018 (Table 4). This sulfur treatment was statistically equivalent to the captan high-rate treatment, which provided $86 \%$ control in 2017 and $71 \%$ control in 2018. Except for the low disease severity category (1 to 10 lesions) in 2018, the high rate of ziram also significantly controlled scab development in both years, providing $68 \%$ control in 2017 and $48 \%$ control in 2018 . However, as evident from the lower percentage control values, ziram-treated fruit generally had higher scab levels than observed on fruit treated with the sulfur and high-rate captan.

\section{Discussion}

Results of the full-season captan cover spray programs in this study provided further evidence that these applications consistently contribute to management of brown rot at harvest. Beginning with the initial "discovery" treatment in 2010, significant reductions in brown rot have been observed across 10 individual treatments conducted over a 6-year period in the current and previous study (Lalancette et al. 2017). Furthermore, bioassay results have always shown the presence of an effective captan residue that significantly reduced conidia germination on fruit during the preharvest fruit ripening period. Except for the 2018 low-rate captan treatment in the current study, the captan cover spray program has always provided $\geq 50 \%$ control of brown rot at harvest, with an average 57\% control achieved across all treatments and years.

As the concentration of captan applied in the cover sprays increased, the percentage of brown rot observed at harvest decreased in a nonlinear fashion. Relative to the "standard" high rate used in all previous studies, application of the low rate resulted in significantly more disease in one of the two years. However, application of the medium rate did not result in a significant disease increase over the high rate in both years. Thus, the medium rate, which provided 51 to $69 \%$ control, was deemed most acceptable for the refined cover spray program. Given the mathematical relationship between rate and disease control, use of concentrations beyond the high rate would probably not provide significant increases in control.

Although use of captan for all cover spray applications is commercially acceptable, results showed that only the final two applications, just before the preharvest fruit ripening period, are necessary to achieve significant control of brown rot at harvest. This finding agrees with results of the bioassay, which showed the presence of effective captan residue during the preharvest period. Apparently, a long buildup of residue from many cover sprays is not needed to achieve control. As further evidence, the late season program, which provided an average 59\% control across both years, was as effective as the full-season high-rate program.
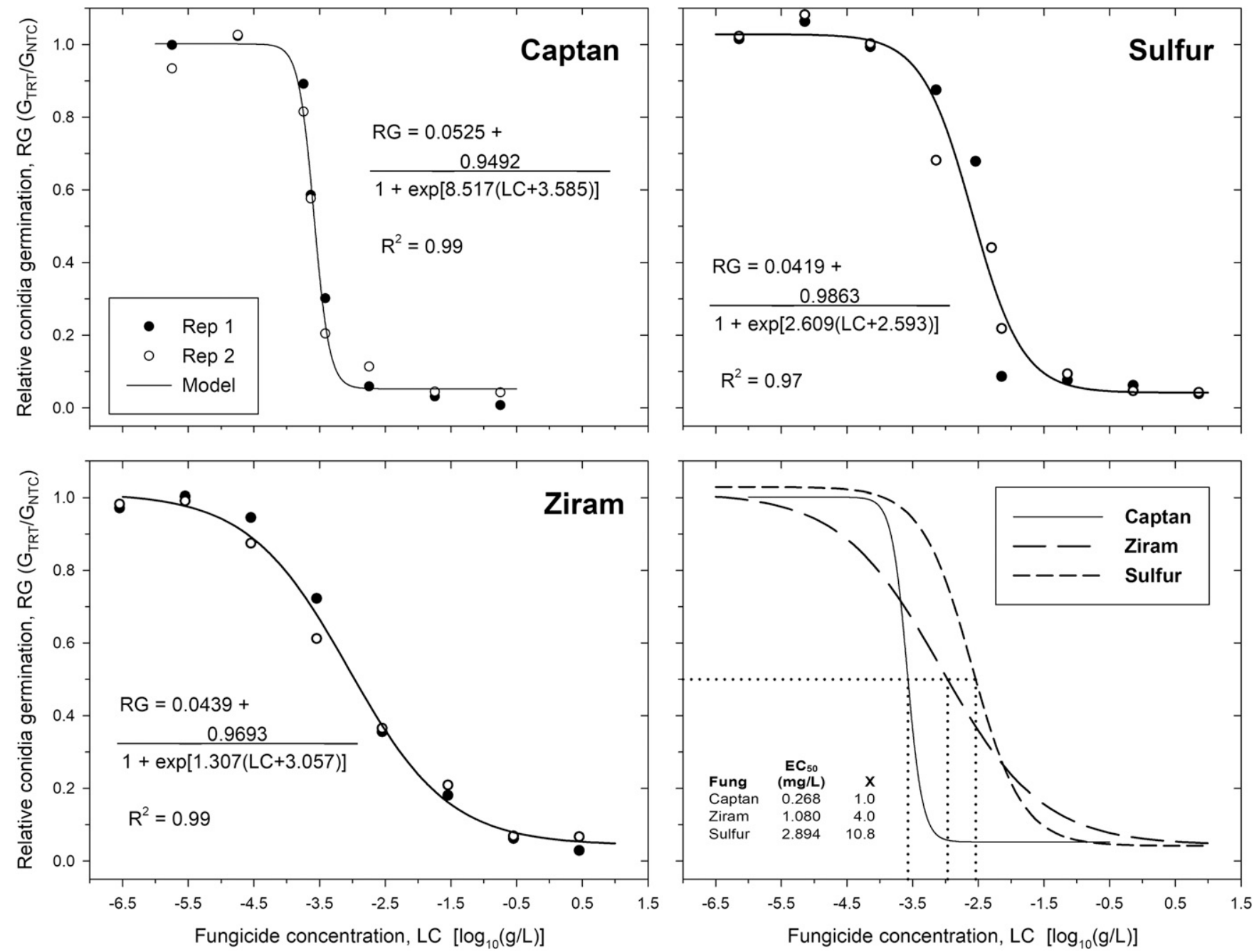

Fig. 1. Dose-response curves quantifying in vitro relative conidia germination (RG) of Monilinia fructicola as a function of fungicide concentration. Logistic decline models were derived from nonlinear regression analyses on pooled data from both replicates. The dependent variable, RG, was calculated as percentage germination for treated conidia ( $\mathrm{G}_{T R T}$ )/ percentage germination for nontreated conidia $\left(\mathrm{G}_{\mathrm{NTC}}\right)$. Each replicate data point was based on observations of 600 conidia ( 3 reps $\times 200$ conidia/rep). $\mathrm{EC}_{50} \mathrm{values}$ for each fungicide were calculated from derived models. The factor $x$ represents efficacy relative to captan efficacy, where $x=E_{50}$ fungicide/EC $\mathrm{C}_{50}$ for captan. 
As hypothesized, the midseason cover spray program was not effective for controlling brown rot, yielding only 0 to $12 \%$ control. Insufficient residue survived the long period from the final fourth cover spray to harvest. In contrast, the early season program provided $40 \%$ disease control for both years. Because the bioassay showed that a residue was not present on fruit during the preharvest period, control for this treatment must have originated at the time of the spray applications, namely shuck split through second cover. Similarly, studies on prunes in California showed that early summer sprays effectively reduced brown rot at harvest (Michailides et al. 1995). Young green fruits at this time are susceptible to infections, which remain quiescent or latent until fruit ripening, when they become active and develop into normal lesions (Ogawa et al. 1995). Observations and evidence of quiescent or latent infections have been reported in California (Wilson and Ogawa 1979), Australia (Jenkins and Reinganum 1965; Jerome 1958; Wade 1956), Ontario (Northover and Cerkauskas 1994), and most recently in Georgia peach orchards (Emery et al. 2000). However, the incidence of quiescent infections in the Georgia study, which included both abandoned and nonsprayed orchards, was quite low at $<2 \%$ fruit infection. In contrast, the circumstantial evidence from the current study, namely the $40 \%$ disease control obtained, appears to indicate a much higher and therefore more significant level of quiescent infection. Thus, additional studies that directly assess the level of latent infection by using one or more techniques (Michailides et al. 2000; Northover and Cerkauskas 1994) are needed to confirm whether high levels of quiescent infections are now commonly occurring in eastern orchards. A warmer, wetter climate may be playing a role in promoting early fruit infection.

If high amounts of quiescent infections are confirmed, then one possible cause in this study may have been the presence of high inoculum during the susceptible period before pit hardening. Significant numbers of sporulating cankers may have formed because fungicide applications for control of blossom blight were not applied. Moderate to severe blossom blight development has been correlated with the incidence of latent fruit infection (Jenkins and Reinganum 1965). Furthermore, recent studies on prune showed a linear increase in incidence of latent fruit infection with increasing inoculum concentration (Luo and Michailides 2001). Although canker assessments were not conducted in this study, canker incidence on shoots in the previous study (2012 to 2015), which was performed in the same orchard, ranged from 15 to $31 \%$ on nontreated trees (Lalancette et al. 2017).
The inability of high rates of sulfur and ziram to provide significant control of brown rot at harvest was probably caused by their low intrinsic efficacy. In the previous study, sulfur and ziram were applied at 10.76 and $5.32 \mathrm{~kg} / \mathrm{ha}$, respectively, in the cover spray applications. In the current study, the sulfur and ziram rates were increased to allowable maximums of 16.14 and $6.81 \mathrm{~kg} / \mathrm{ha}$, respectively. Thus, the ziram and sulfur rates were increased by only a factor of 1.5 and 1.3 , respectively, between the two studies. However, comparison of $\mathrm{EC}_{50}$ concentrations from the dose-response curves showed that sulfur and ziram required an 11- and four-fold increase in concentration to be as effective as captan. Product rate ranges in the current registrations do not allow such increases.

Rainfall did not appear to have a significant effect on reducing the efficacy of the captan residue on fruit. During the preharvest periods from the final cover spray to harvest, high rainfall accumulations ranging from 8.1 to $19.2 \mathrm{~cm}$ were observed in 2010 and 2013 in the previous study (Lalancette et al. 2017) and in both 2017 and 2018 in the current study. Conversely, lower amounts of rainfall accumulation in the previous study in $2012(3.63 \mathrm{~cm})$ and 2015 $(1.91 \mathrm{~cm})$ may have increased the potential for photodegradation from sunlight. Nevertheless, in either case, significant reductions in brown rot at harvest were always observed, with control ranging from 50 to $78 \%$. This ability of captan to provide durable control under adverse environmental conditions may well be caused by its high intrinsic efficacy rather than the ability of the fungicide formulation to resist wash-off or degradation. Additional captan formulations must be examined.

Peach scab was adequately controlled by both the medium- and high-rate captan cover spray programs, which provided 71 to $86 \%$ control under very heavy disease pressure. This observation agrees with the previous study, which had similar levels of scab control, ranging from 82 to $86 \%$ (Lalancette et al. 2017). As would be expected, only the early and midseason cover spray programs provided scab control, because this is the period during which overwintering scab lesions are actively producing inoculum for infection (Lalancette et al. 2015b; Scherm et al. 2008). The late season applications were applied after the infectious period and therefore had no effect on scab development. Finally, as observed in the previous study, sulfur provided effective management of scab, whereas ziram, even at the higher rate, did not consistently control scab, yielding only $48 \%$ control in 2018.

An improved peach cover spray program, which provides control for both brown rot and scab, can be constructed given the results of

Table 4. Peach scab incidence and severity at harvest for cover spray fungicide treatments applied during the 2017 and 2018 growing seasons

\begin{tabular}{|c|c|c|c|c|c|c|c|c|c|}
\hline \multicolumn{4}{|c|}{ Treatment } & \multicolumn{3}{|c|}{$2017^{y}$} & \multicolumn{3}{|c|}{$2018^{y}$} \\
\hline \multirow[b]{2}{*}{ Type } & \multirow[b]{2}{*}{ Fungicide } & \multirow{2}{*}{$\begin{array}{c}\text { Amount } \\
(\mathrm{kg} / \mathrm{ha})\end{array}$} & \multirow[b]{2}{*}{ Application timing ${ }^{\mathrm{z}}$} & \multirow[b]{2}{*}{$\%$ Fruit infected } & \multicolumn{2}{|c|}{$\%$ Fruit with: } & \multirow[b]{2}{*}{$\%$ Fruit infected } & \multicolumn{2}{|c|}{ \% Fruit with: } \\
\hline & & & & & 1-10 lesions & $>10$ lesions & & 1-10 lesions & $>10$ lesions \\
\hline Nontreated & - & - & - & $74 \mathrm{a}$ & $34 \mathrm{a}$ & $40 \mathrm{a}$ & $84 \mathrm{a}$ & $33 a b c$ & $51 \mathrm{a}$ \\
\hline \multirow[t]{2}{*}{ Standard } & Captan & 3.36 & SS, $1 \mathrm{C}-6 \mathrm{C}$ & & & & & & \\
\hline & Fenbuconazole & 0.158 & $15,6-8 \mathrm{dph}$ & $2 \mathrm{e}$ & $2 \mathrm{e}$ & $0 \mathrm{~d}$ & $14 \mathrm{f}$ & $11 \mathrm{~d}$ & $3 \mathrm{c}$ \\
\hline \multicolumn{10}{|c|}{ Fungicide rate effect } \\
\hline Low rate & Captan & 2.24 & SS, $1 \mathrm{C}-6 \mathrm{C}$ & 12 cde & 10 cde & $2 \mathrm{~d}$ & $47 \mathrm{~cd}$ & $38 a b$ & $9 \mathrm{c}$ \\
\hline Medium rate & Captan & 2.80 & SS, $1 \mathrm{C}-6 \mathrm{C}$ & $21 \mathrm{~cd}$ & $20 \mathrm{bc}$ & $1 \mathrm{~d}$ & $22 \mathrm{f}$ & $16 \mathrm{~cd}$ & $6 c$ \\
\hline High rate & Captan & 3.36 & SS, $1 \mathrm{C}-6 \mathrm{C}$ & $10 \mathrm{de}$ & 10 cde & $0 \mathrm{~d}$ & 24 ef & $15 \mathrm{~cd}$ & $9 \mathrm{c}$ \\
\hline \multicolumn{10}{|c|}{ Fungicide timing effect } \\
\hline Early season & Captan & 3.36 & $\mathrm{SS}, 1 \mathrm{C}, 2 \mathrm{C}$ & $7 \mathrm{e}$ & $7 \mathrm{de}$ & $0 \mathrm{~d}$ & $41 \mathrm{de}$ & 24 abcd & $17 \mathrm{bc}$ \\
\hline Midseason & Captan & 3.36 & $3 \mathrm{C}, 4 \mathrm{C}$ & $49 \mathrm{~b}$ & $30 \mathrm{ab}$ & $19 \mathrm{~b}$ & $60 \mathrm{bc}$ & $42 \mathrm{a}$ & $18 \mathrm{bc}$ \\
\hline Late season & Captan & 3.36 & $5 \mathrm{C}, 6 \mathrm{C}$ & $64 \mathrm{a}$ & $36 \mathrm{a}$ & $28 \mathrm{ab}$ & $75 a b$ & $42 \mathrm{a}$ & $33 a b$ \\
\hline \multicolumn{10}{|c|}{ Alternative protectants } \\
\hline High rate & Sulfur & 16.14 & SS, $1 \mathrm{C}-6 \mathrm{C}$ & $5 \mathrm{e}$ & $5 \mathrm{e}$ & $0 \mathrm{~d}$ & $18 \mathrm{f}$ & $16 \mathrm{~cd}$ & $2 \mathrm{c}$ \\
\hline High rate & Ziram & 6.81 & $\mathrm{SS}, 1 \mathrm{C}-6 \mathrm{C}$ & $24 \mathrm{c}$ & $17 \mathrm{~cd}$ & $7 \mathrm{c}$ & $44 \mathrm{~cd}$ & $22 \mathrm{bcd}$ & $22 \mathrm{bc}$ \\
\hline
\end{tabular}

${ }^{y}$ Means in the same column followed by the same letter are not significantly different according to the Waller-Duncan $K$-ratio $t$ test $(K$-ratio $=100 ; P \leq 0.05)$. All results are based on a sample size of 25 fruits/tree for a total of 100 fruits/treatment.

${ }^{z}$ The fenbuconazole in the standard treatment was applied at 15 and 6 dph in 2017 and at 15 and 8 dph in 2018. 1C-6C, first through sixth covers; dph, days preharvest; SS, shuck split. 
this refinement study. First, fungicide applications from early shuck split $(<5 \%)$ through initiation of pit hardening (approximately $2 \mathrm{C}$ ) must be effective for management of quiescent brown rot infections on young, green fruit. Even if these infections are generally low in incidence, it would be prudent to provide control at this time given our findings. These applications also must be effective for control of peach scab because scab lesion sporulation is active during this period. Captan can certainly provide control of both diseases during this time, although many other fungicides are also available; materials more effective for scab control may be needed if scab pressure is high. Second, the midseason fungicide applications must be effective only for scab control, because older green fruits are not susceptible to brown rot infection. This period may encompass only one or two cover sprays for early season cultivars to as many as four or five for late season cultivars. Sulfur is a good choice given its lower cost, although more effective scab materials may be needed. Finally, the last two cover sprays, just before the preharvest period, should consist of captan at the medium or high rate.

The final two captan applications in the above-defined cover spray program provide a number of benefits at little or no additional cost to commercial growers. First, brown rot control at harvest should be more consistent from year to year because an effective residue will be present regardless of the weather conditions. In particular, if rainy conditions during the preharvest period prevent timely application of the site-specific fungicides, an effective cap$\tan$ residue is already present to reduce loss. Second, preharvest brown rot control will no longer be dependent solely on the sitespecific fungicides but also a function of control from the cover spray program. Thus, the overall level of control achieved by the site-specific materials should be high because $\geq 50 \%$ of the control is already being provided by the captan. Under very high disease pressure, the 93 and $98 \%$ control achieved by the standard treatments is evidence of this combined action. Third, fungicide resistance development by $M$. fructicola has become problematic for the highly effective at-risk systemic fungicides commonly used during the preharvest period (Amiri et al. 2010; Burnett et al. 2010; Chen et al. 2013). The presence of the captan residue, along with the use of several different site-specific chemistries, should act as an effective resistance management strategy. And as a multisite protectant fungicide, captan itself is not at risk for resistance development, so this resistance management strategy should be sustainable. Fourth, preharvest fungicides that typically provide good or very good brown rot control may well yield excellent control when combined with captan cover sprays. Thus, the palette of available preharvest fungicides and different chemistries may be larger. Finally, and perhaps most importantly, this strategy does not require commercial growers to apply any additional fungicide applications; they would only need to switch from other materials, such as sulfur, to captan in the final two cover sprays.

\section{Literature Cited}

Amiri, A., Brannen, P. M., and Schnabel, G. 2010. Reduced sensitivity in Monilinia fructicola field isolates from South Carolina and Georgia to respiration inhibitor fungicides. Plant Dis. 94:737-743.

Anderson, H. W. 1956. Diseases of drupe or stone fruits Pages 189-205 in: Diseases of Fruit Crops. McGraw-Hill Book Co., New York.

Bernstein, B., and Miller, R. W. 1995. Anthracnose. Pages 18-19 in: Compendium of Stone Fruit Diseases. J. M. Ogawa, E. I. Zehr, G. W. Bird, D. F. Ritchie, K.
Uriu, and J. K. Uyemoto, eds. The American Phytopathological Society, St. Paul, MN.

Burnett, A., Lalancette, N., and McFarland, K. 2010. First report of the peach brown rot fungus Monilinia fructicola resistant to demethylation inhibitor fungicides in New Jersey. Plant Dis. 94:126.

Chen, F., Liu, X., and Schnabel, G. 2013. Field strains of Monilinia fructicola resistant to both MBC and DMI fungicides isolated from stone fruit orchards in the eastern United States. Plant Dis. 97:1063-1068.

Darby, R. T. 1960. Fungicide assay by spore germination in shaker flasks. Appl. Microbiol. 8:146-148.

Emery, K. M., Michailides, T. J., and Scherm, H. 2000. Incidence of latent infection of immature peach fruit by Monilinia fructicola and relationship to brown rot in Georgia. Plant Dis. 84:853-857.

Furman, L. A., Lalancette, N., and White, J. F., Jr. 2003. Peach rusty spot epidemics: management with fungicide, effect on fruit growth, and the incidence -lesion density relationship. Plant Dis. 87:1477-1486.

Hendrix, F. F., Jr. 1995. Scab. Pages 11-12 in: Compendium of Stone Fruit Diseases. J. M. Ogawa, E. I. Zehr, G. W. Bird, D. F. Ritchie, K. Uriu, and J. K. Uyemoto, eds. The American Phytopathological Society, St. Paul, MN.

Jenkins, P. T., and Reinganum, C. 1965. The occurrence of quiescent infection of stone fruits caused by Sclerotinia fructicola (Wint.). Rehm. Aust. J. Agric. Res. 16:131-140.

Jerome, S. M. R. 1958. Brown rot of stone fruits: latent contamination in relation to spread of disease. J. Aust. Inst. Agric. Sci. 24:132-140.

Jones, A. L. and Sutton, T. B. 1996. Diseases of Tree Fruits in the East. Michigan State University Extension, NCR Ext. Bull. 45:63, 76.

Lalancette, N., and Blaus, L. 2018. Refinement of peach cover spray programs for sustainable management of brown rot. (Abstr.). Phytopathology 108: S1.148.

Lalancette, N., Blaus, L. L., Gager, J. D., and McFarland, K. A. 2017. Contribution of mid-season cover sprays to management of peach brown rot at harvest. Plant Dis. 101:794-799.

Lalancette, N., Gager, J., and McFarland, K. A. 2015a. An in vivo bioassay for estimating fungicide residues on peach fruit. Plant Dis. 99:1727-1731.

Lalancette, N., McFarland, K. A., and Burnett, A. L. 2015b. Influence of trifloxystrobin on primary inoculum and progression of scab epidemics on stone fruit. Plant Dis. 99:467-473.

Luo, Y., and Michailides, T. J. 2001. Factors affecting latent infection of prune fruit by Monilinia fructicola. Phytopathology 91:864-872.

Michailides, T. J., Morgan, D. P., and Felts, D. 2000. Detection and significance of symptomless latent infection of Monilinia fructicola in California stone fruit. (Abstr.). Phytopathology 90 (suppl.):S53.

Michailides, T. J., Morgan, D. P., Holtz, P. A., and Hong, C. 1995. Biology, ecology, and epidemiology of Monilinia species, and management of prune brown rot with late-spring and early-summer fungicide sprays. Pages 79-100 in: Prune Research Report and Index of Prune Research. California Prune Board, Pleasanton.

Northover, J., and Cerkauskas, R. F. 1994. Detection and significance of symptomless latent infections of Monilinia fructicola in plums. Can. J. Plant Pathol. 16:30-36.

Ogawa, J. M., Zehr, E. I., and Biggs, A. R. 1995. Brown rot. Pages 7-10 in: Compendium of Stone Fruit Diseases. J. M. Ogawa, E. I. Zehr, G. W. Bird, D. F. Ritchie, K. Uriu, and J. K. Uyemoto, eds. The American Phytopathological Society, St. Paul, MN.

Scherm, H., Savelle, A. T., Boozer, R. T., and Foshee, W. G. 2008. Seasonal dynamics of conidial production potential of Fusicladium carpophilum on twig lesions in southeastern peach orchards. Plant Dis. 92:47-50.

Wade, G. C. 1956. Investigations on brown rot of apricots caused by Sclerotinia fructicola (Wint.) Rehm I. The occurrence of latent infection in fruit. Aust. J. Agric. Res. 7:504-515.

Ward, D., Besancon, T., Gohil, H., Hamilton, G., Heckman, J., Lalancette, N., Nielsen, A., and Polk, D. 2017. Peach and nectarine spray guide. Pages 76-103 in: The New Jersey Commercial Tree Fruit Production Guide. New Jersey Agric. Exp. Stn., Rutgers Coop. Ext. Bull. E002.

Wilson, E. E., and Ogawa, J. M. 1979. Fungal, bacterial, and certain nonparasitic diseases of fruit and nut crops in California. Agric. Sci. Publ. University of California, Berkeley. 